\title{
OS TRÊS OLHARES: O USO DA IMAGEM NO ENSINO DE LÍNGUA PORTUGUESA
}

\author{
MÁRCIO FAGUNDES BARCELOS ${ }^{1}$ \\ rockissimo@comnet.com.br
}

\begin{abstract}
The main point of this article is to present relationship aspects between images and texts production. It is based on the Os Três Olhares technique to that the students can make a text with the interaction with the looking object: the image. This technique is used like way to be easy the texts production among High School students who want to get in the university. It's necessary because develop the internal feelings between the students in little groups or students alone to reach wanted results in the classroom.
\end{abstract}

KEYWORDS: Interaction. Images. Texts production. Groups.

\section{INTRODUÇÃO}

Para a elaboração do presente artigo, cuja idéia central é a aplicação do uso de imagens na aquisição da linguagem e na produção textual, baseamo-nos nas palavras de Richter (2000) sobre a Teoria da Percepção de Peirce: "Perceber um objeto é criar, na mente, algo relacionado e causado por alguma coisa exterior, material". (p. 32)

A nosso ver, a relação de interação que se faz entre o externo (objeto, linguagem que entra) e o interno (definição, linguagem que sai) dá-se, com o sentido da visão sem, necessariamente, usarmos palavras - ou textos. Mas também como forma de interpretação do que se vê em imagens.

Numa perspectiva interacionista, veremos que a metodologia Os Três Olhares serve como forma prática no reconhecimento dos signos e na produção textual.

\section{A Imagem como Objeto a ser "Decifrado"}

"Lemos superficialmente, 'passamos os olhos'.

Não acrescentamos ao ato de ler algo mais de nós além do gesto mecânico de decifrar os sinais".

(Gil Carlos Pereira)

1 Aluno do Curso de Especialização em Lingüística, Literatura e Ensino de Línguas da UNICRUZ. 
Interpretar uma imagem não consiste apenas em encontrar o seu sentido aparente, mas em compreender o que significa num contexto social e no contexto do interpretante (observador). Daí a importância de se observar múltiplos conceitos: o que representa para um interpretante, pode significar outra coisa para outro e ter um significado real diferente desses dois. Observemos o exemplo de uma chave mostrada para uma pessoa: pode representar "abrir muitas portas", "desvendar segredos", "encerrar-se numa jaula" ou apenas um objeto como muitos outros sem muita utilidade. Esses conceitos poéticos influenciam na real interpretação e, criar textos ou assimilar conceitos a partir de uma única observação, pode gerar liberdade e ser negativo a partir do momento em que se encerra tal procedimento.

Por imagem como objeto podemos utilizar coisas avulsas (como a chave), idéias fixas (viagem de férias), figuras (desenhos, charges, histórias em quadrinhos). Portanto, propor a análise de imagens provoca reticências sobre vários aspectos, se contesta também a riqueza de uma mensagem visual através de um repetitivo e inevitável; é a arte a qual não seria da ordem do intelecto, mas do afetivo e do emotivo, da subjetividade do receptor.

\section{RELAÇÃO TEXTO E IMAGEM}

Partindo dos exemplos de figuras, charges ou quadrinhos com balões em branco, pode-se fazer o quadro-a-quadro que dá movimento e materialidade à expressão, imprimindo ilusão narrativa a uma reflexão atemporal, com a linearidade do verbo e a simultaneidade da ilustração à época, por exemplo, pegando-se uma charge ou tiras sobre política o aluno parte da relação mental e social de que o que é ilustrado ali deve ter época específica para ter seu contexto associado com a realidade do leitor (aluno) para não correr o risco de dizer apenas que vê um homenzinho de terno e gravata carregando uma maleta preta, e só.

Scott McCloud, em "Desvendando os Quadrinhos" sistematiza a relação entre texto e imagem com sete passos ordenados ou não no desfecho da imagem ao texto. São eles: Específicos de palavras: imagem ilustra o texto, sem somar informação; Específicos de imagem: texto só comenta seqüência de imagens; duo-específicos: palavras e imagens transmitem a mesma mensagem; Aditivo: as palavras ampliam o sentido manifesto da imagem; Paralelos: não há relação entre texto e imagem. Cada um emite mensagem diferente, sem se fundirem; Montagem: as palavras são a própria imagem; Interdependente: imagens e palavras emitem idéia que não conseguiram em separado. $O$ desafio para o aluno seria a "interdependência" de McCloud: estabelecer tal diálogo entre imagem e texto que evite redundâncias, uma coincidência entre representante textual e referente figurativo. Seqüenciado, o texto-imagem viraria unidade visual e forma e conteúdo seriam o resultado esperado pelo professor.

\section{Os Três Olhares}


Costuma-se ignorar, quase que a todo o instante, os "sinais" que recebemos/percebemos em nosso dia-a-dia. Direcionamos nossa atenção ao que nos interessa de fato e não damos importância ao que parece "marginal". Contudo, os sinais podem ser tratados como forma de elaboração do pensamento em sala de aula. Apresentaremos agora uma técnica que pode ser aplicada à leitura e produção textual dos mais diversos tipos de texto: jornalístico, poético, narrativo, um conto, uma tira de quadrinhos. Para percebermos os sinais que recebemos todos os dias, precisamos exercitar nosso olhar e construirmos o pensamento (e o texto) por meio do olhar e, conseqüentemente, da palavra.

Com a metodologia dos Três Olhares, podemos exercitar os três momentos do "pensar": a apreensão, a compreensão e a conceituação/síntese.

A apreensão baseia-se em ver os elementos significativos do texto; a compreensão em dar sentido aos elementos levantados e a conceituação em incorporar esses elementos à nossa realidade.

É uma metodologia que usamos em nosso dia-a-dia sem dar-lhe a devida importância, quase intuitivamente. Exemplificando, podemos compará-las às etapas que percorremos quando conhecemos alguém, ou seja:

a) num primeiro encontro, observamos a pessoa em suas características externas, físicas, pessoais;

b) no segundo encontro, já tecemos alguns comentários sobre a personalidade daquela pessoa. Passamos a conhecê-la melhor e ela já faz sentido para nós;

c) no terceiro encontro, nos identificamos com ela. Tem início um processo de conhecimento mais profundo. Há um cruzar de sentidos.

Assim, também, acontece com relação ao objeto (imagem, figura, texto). Identificar um objeto e inteirar-se com ele tem a ver com o levantamento das possibilidades, das suspeitas. É necessário dar um significado a ele e trazê-lo para a nossa realidade, contextualizar.

Trabalhando em grupos, mostra-se para todos os grupos uma janela com as venezianas abertas e o vidro fechado. Para cada grupo dá-se um "objeto estranho" ao visual primeiramente visto (mostra-se a mesma janela, mas com "acessórios"): para um grupo, exibe-se uma cortina "batendo", para outro um barco passando do lado de fora, para outro um rato na janela, para outro chuva do lado de fora... todos juntos no mesmo desenho da janela.

\section{Metodologias e Técnicas}

1Ohar: é o ENCONTRO com o objeto. É VER o objeto e fazer a COKHEITA de: sinais significativos, sugestões, coisas diferentes, suspeitas.

Técnica: $O$ que o objeto mostra? O autor se refere a quê? O objeto trabalha sobre o quê? Que suspeitas ele abre? Parece com o quê? O que é? 
2o Olhar: é o olhar da DEVASSA. É o ACOLHIMENTO do que se viu no objeto. É aceitar e reconhecer sentido entre a vida vivida e a representada. É um JULGAR, um olhar analítico.

Técnica: Há uma seqüência lógica? De que forma se criam as imagens e que significados elas têm?

3o Olhar: é o olhar do MERGULHO no objeto. É hora de RECOLHIMENTO. A INTERAÇÃO e o AGIR. Da INTIMIDADE com o objeto.

Técnica: como o observador interpreta o que foi mostrado a ele? O que isso tem a ver com a sua realidade? Que sentido o observador dá ao objeto?

\section{CONSIDERAÇÕES FINAIS}

Trabalhar com a técnica Os Três Olhares é uma oportunidade de fazer a interpretação do que se vê indiferente do que realmente o é. Como forma de produção textual, serve como segmentação a outras formas de trabalho, inclusive de assimilação de regras gramaticais, pois, se um aluno produz um texto interpretativo a partir da observação de uma história em quadrinhos - por exemplo - com os balões em branco, terá, intuitivamente, que ordenar as idéias e dar-Ihes coerência e coesão para entendimento. Essa técnica foi utilizada no estágio supervisionado de prática docente no ano de 2001 numa escola municipal para o Ensino Médio em Língua Portuguesa e Fundamental em Língua Inglesa com resultados satisfatórios. Como vimos, o uso de técnicas que deixem o ensino de Língua Portuguesa mais atraente, pode estreitar a relação professor/aluno, facilitando suas relações, inclusive, entre colegas em sala de aula, pois o conflito de idéias ajuda a criar relações saudáveis e de auxílio mútuo.

\section{REFERÊNCIAS BIBLIOGRÁFICAS}

ACEVEDO, Juan. Como Fazer Histórias em Quadrinhos. São Paulo: Global Editora, 1990.

DIAS-PINO, Wlademir. Processo: Linguagem e Comunicação. Petrópolis: Vozes, 1973.

McCLOUD, Scott. Desvendando os Quadrinhos. São Paulo: Mbooks, 2005.

MOYA, Álvaro de. História da História em Quadrinhos. São Paulo: Ed. Brasiliense, 1993.

PEREIRA, Gil Carlos. A Palavra - expressão e criatividade. São Paulo: Ed. Moderna, 1997.

RICHTER, Marcos Gustavo. Ensino do Português e Interatividade. Santa Maria: Ed. UFSM, 2000.

SOUZA, Cássia Leslie Garcia de. Linguagem: criação e interação. São Paulo: Saraiva, 2002. 